\title{
In vitro Antifungal Activity of Aegle marmelos, Syzygium cumini and Pongamia pinnata Extracts against Fusarium oxysporum f. sp. cicero
}

\author{
Y. D. MORE, R. M. GADE AND A. V. SHITOLE* \\ Department of Plant Pathology, Dr. Panjabrao Deshmukh Krishi Vidyapeeth, Akola-444 104, India
}

More, et al.: Antifungal Efficacy of Medicinal Plants Extracts against Fusarium oxysporum f. sp. ciceri

The present investigation was carried out using acetone, ethanol, methanol and chloroform extracts of different plants and bio agents against Fusarium oxysporum $f$. sp. ciceri. Effect of plant extracts and bio agents alone and in combination on wilt incidence of chickpea was assessed using pot culture method. Methanol extracts of Aegle marmelos was found most active (88.64\%) followed by methanol extract of Pongamia pinnata (85.30\%). Ability of these four solvents to produce maximum extraction yield from four different plants was also evaluated. Methanol extracts of $A$. marmelos at concentrations of $250,500,750$ and $1000 \mu \mathrm{l}$ was found compatible with Trichoderma viride and Pseudomonas fluorescens. Methanol also gave the highest percent extraction yield. Seed treatment with $P$. fluorescens $10 \mathrm{~g} / \mathrm{kg}$ seed+T. viride $4 \mathrm{~g} / \mathrm{kg}$ seed+methanol extract of $A$. marmelos $4 \%$ proved effective to reduce incidence of chickpea wilt disease caused by F. oxysporum $f$. sp. ciceri $(69.31 \%)$.

Key words: Extracts, antifungal activity, A. marmelos, $S$. cumini, $P$. pinnata, F. oxysporum $f$. sp. cicero

Fungal diseases of crop plants have always been one of the major constraints in successful crop production, which cause severe yield loss every year. Injudicious use of synthetic fungicides for controlling plant diseases have given rise to negative effects on human and animal health and agro-ecosystem. Researchers continue to strive to develop alternatives to chemical fungicides. Eco-friendly methods involving plant products and biological agents, which act directly on the pathogens or indirectly by inducing resistance in plants, have gained considerable importance as an alternative to using synthetic fungicides ${ }^{[1]}$.

Chemical fungicides pollute the environment, soil

This is an open access article distributed under the terms of the Creative Commons Attribution-NonCommercial-ShareAlike 3.0 License, which allows others to remix, tweak, and build upon the work non-commercially, as long as the author is credited and the new creations are licensed under the identical terms

Accepted 14 April 2017

Revised 02 January 2017

Received 15 June 2016

Indian J Pharm Sci 2017;79(3):457-462 
and water besides being deleterious to human health and environment, necessitating a continuous search for an environmentally safe and economically viable strategy to control the fungal diseases and to reduce the dependence on synthetic agrochemicals. Natural products or plant extracts have the potential to be employed as leads for synthesis of new agrochemicals or directly as fungicides, which inspired biochemists to develop new bioassays capable of detecting other, structurally simpler compounds with similar modes of action. Medicinal plants may thus prove to be a new source for antibacterial, antifungal and antiviral agents with significant activity against microorganisms ${ }^{[2]}$. As the synthetic fungicides are toxic to plants and have the potential to enter food chain leading to bioaccumulation, the focus must be to develop eco-friendly and effective methods to control plant diseases, and one such approach is employing medicinal plants ${ }^{[3]}$.

Plant metabolites and plant-based pesticides could prove to be a better alternative with minimal environment impact and safer in contrast to synthetic pesticides ${ }^{[4]}$. Active principles from medicinal plants have been tried as replacements for synthetic fungicides in management of plant diseases in organic farming system. Plant extracts could have unique antimicrobial properties with a holistic mode of action. There have been reports in the literature that plant extracts and their constituents such as alkaloids, terpenoids, glycosides and phenolic acids possessed antimicrobial activity ${ }^{[5]}$.

Phytochemical analysis of Aegle marmelos revealed the presence of alkaloids, saponins, tannins, flavonoids and furanocoumarins ${ }^{[6]}$. Employing aqueous extracts of many allelopathic plants and utilization of microbial antagonists as the environmentally safe alternative methods for plant disease management appears to be the need of the hour for efficient integrated disease management strategies.

The wilt of chickpea incited by Fusarium oxysporum $f$. $s p$. ciceri is one of the serious disease ${ }^{[7]}$. This soil ${ }^{[8]}$ and seedborne ${ }^{[9]}$ pathogen causes profound losses (20 to $100 \%$ ) depending upon phase of illness and wilting ${ }^{[10]}$. A systematic investigation was undertaken to screen the antifungal activity and explore the possibilities of utilizing these for management of wilt of chickpea under laboratory conditions against $F$. oxysporum f. sp. ciceri.

A virulent isolate of $F$. oxysporum f. sp. ciceri isolated from wilt-infested chickpea plants was used in this investigation. Chickpea variety JG-62 was used as a host crop. Two antagonists viz., Trichoderma harzianum and Pseudomonas fluorescens isolated from soil sample were collected from department of plant pathology, Dr. P. D. K. Vidyapeeth, Akola. The experiment was conducted in vitro and under greenhouse conditions during 2015 in the department of plant pathology, Dr. P. D. K. Vidyapeeth, Akola. The sand sorghum medium (SSM) was used for the mass multiplication of $F$. oxysporum $f$. sp. ciceri in the laboratory.

Fresh leaves of A. marmelos, Syzygium cumini and Pongamia pinnata were collected from various places nearby the institution. Identification and authentication of the plants was carried out at Nagarjun Medicinal Plants Garden, Dr. P. D. K. Vidyapeeth, Akola, India. The fresh plant leaves collected were thoroughly washed under tap water first followed by distilled water to remove dirt and impurities, and shade-dried separately with occasional shifting for about 3 to 4 w. The dried leaves were coarsely powdered with a sample grinder and stored in airtight container until further use ${ }^{[11]}$.

Acetone, ethanol, methanol and chloroform were used as solvents for preparing leaf extracts. Forty gram powder of each leaf was separately soaked in $200 \mathrm{ml}$ of acetone, ethanol, methanol and chloroform in $500 \mathrm{ml}$ conical flasks plugged tightly with cotton wrapped in paper. All conical flasks were kept on a rotary shaker for $4 \mathrm{~d}$ and allowed to stand for $5 \mathrm{~h}$ for the marc to settle. Supernatants from each flask were filtered separately through Whatman No. 1 filter paper and evaporated at room temperature. The marc was extracted three times to harvest maximum from the leaf powder. Air dried extracts were weighed separately and transferred into small vials and kept in the refrigerator at $5^{\circ}$ until further use. The percent extraction yield was calculated ${ }^{[12]}$.

The efficacy of acetone, ethanol, methanol and chloroform extracts of $A$. marmelos, $S$. cumini and $P$. pinnata at 250, 500, 750 and $1000 \mu \mathrm{l}$ concentration were tested against. $F$. oxysporum $f$. sp. ciceri under in vitro condition following poisoned food technique on potato dextrose agar (PDA) ${ }^{[13]}$. One gram crude extract of all plants extracted with acetone, ethanol, methanol and chloroform were diluted in $10 \mathrm{ml}$ dimethyl sulphoxide (DMSO) separately and from this $250,500,750$ and $1000 \mu \mathrm{l}$ suspension were added to conical flasks containing $60 \mathrm{ml}$ sterilized melted PDA medium sufficient for 3 plates. The conical flasks were shaken well for uniform mixing, the contents poured in 
to plates the plates were allowed for solidification. In the control set, only 250, 500, 750 and $1000 \mu 1$ DMSO were used. For each treatment, plates in triplicate were used. All the plates were inoculated individually with $5 \mathrm{~mm}$ diameter discs of the test fungal cultures and incubated at $28 \pm 2^{\circ}$, until the control plates reached full growth. To know the effect of different plant extracts. The percent growth inhibition (I) of test fungus was calculated $^{[14]}$.

Present investigation was carried out to study the antagonistic activity of bio agent's $P$. fluorescens and $T$. viride against $F$. oxysporum $f$. sp. ciceri causing wilt of chickpea. Initially, these bio agents were tested in vitro and the promising bio agents were then tested in pot experiment individually as well as in combination with plant extracts as seed treatment. Antagonistic activity of $P$. fluorescens and $T$. viride was studied using the dual culture technique on PDA plates. The inoculated plates were incubated at $28 \pm 2^{\circ}$ for $7 \mathrm{~d}$ for F. oxysporum $f$. $s p$. ciceri. Observations regarding antagonistic effect of all these bio agents against test pathogens were recorded at 3,5 and $7 \mathrm{~d}$ after inoculation. The growth inhibition of each fungal pathogen was calculated ${ }^{[14]}$. Compatibility was determined for T. viride, P. fluorescens and methanol plant leaves extract by poisoned food technique. Spectrophotometric method was followed to study the compatibility of $A$. marmelos leaf methanol extract with potential bacterial bio agents.

Pot culture experiment were carried out for studying antagonistic activity of $P$. fluorescence, $T$. viride and A. marmelos methanol extract alone or in combination as seed treatment against $F$. oxysporum $f$. sp. ciceri. Chickpea JG-62 seeds were surface disinfected in $2 \%$ sodium hypochlorite for $30 \mathrm{~s}$, rinsed in sterile distilled water and dried overnight. Ten seeds were planted per pot filled with sterilized potting soil $(1.5 \mathrm{~kg})^{[15]}$. The inoculum of fungal pathogens multiplied on sand:sorghum medium was added to each pot at 1:20 (w/w) ratio of pathogen to soil. In every treatment, the talc-based formulation of $T$. harzianum and $P$. fluorescens was applied as a seed treatment at 4 and $10 \mathrm{~g} / \mathrm{kg}$ of seed, respectively. In marigold water extract treatment, seeds were soaked in 2, 3 and $4 \%$ solutions separately for $3 \mathrm{~h}$ and air-dried overnight before sowing and inoculated pots with the pathogen alone served as control. Three replications were maintained for each treatment in a factorial completely randomized design (FCRD) in a glasshouse. Incidence of wilt in chickpea was recorded at 30 and $60 \mathrm{~d}$ after sowing.

Treatment details are as follows, S1P1 (acetone extract of $A$. marmelos), S1P2 (acetone extract of $S$. cumini), S1P3 (acetone extract of P. pinnata), $\mathrm{S} 2 \mathrm{P} 1$ (ethanol extract of $A$. marmelos), S2P2 (ethanol extract of $S$. cumini), S2P3 (ethanol extract of $P$. pinnata), S3P1 (methanol extract of A. marmelos), S3P2 (methanol extract of $S$. cumini), S3P3 (methanol extract of $P$. pinnata), S3P4 (methanol extract of P. pinnata), S4P1 (chloroform extract of $A$. marmelos), S4P2 (chloroform extract of S. cumini) and S4P3 (chloroform extract of $P$. pinnata).

In vitro effect of medicinal plant extracts on test pathogen was done by using FCRD with three factors having four levels in each factor. The data was analysed statistically following the method reported by Panse and Sukhatme ${ }^{[16]}$. ' $F$ ' test was used to determine which treatment effects were significant. Standard error (SE) and critical difference (CD) at $1 \%$ level of probability were calculated.

The results revealed that all extracts tested at each concentration inhibited the growth of $F$. oxysporum $f$. sp. ciceri. The rate of inhibition of growth is found to be proportional to the concentrations of the plant extracts tested. Using these medicinal plant wastes as a raw material for plant-derived fungicides, it is possible to manage the disease while creating an economical use for the medicinal plant waste.

Results in Table 1 indicated that the extraction yield was significantly influenced by the extraction solvent chosen, which depended on the polarity and capacity of the solvent to extract chemical constituents. Methanol was found to be most suited for extraction of many substances that are soluble in greater yields from A. marmelos (7.04\%), S. cumini (8.12\%) and P. pinnata (6.81\%).

It was observed from the data in Table 2 that $F$. oxysporum $f$. sp. ciceri was sensitive to all the tested bio agents but $P$. fluorescens extract produced maximum mycelial inhibition $(81.59 \%)$. These results were similar to those reported by Trivedi and Rathi ${ }^{[17]}$, Mohmed and El-Hadidy ${ }^{[18]}$ that the Trichoderma species exhibited greater potential in managing chickpea wilt under glasshouse and field conditions. Selected isolates of $P$. fluorescens were found to be effective in reducing the wilt incidence and increasing the plant growth as well as grain yield of chickpea ${ }^{[19,20]}$. P. fluorescens has revolutionised the field of biological control of soil- 
TABLE 1: EFFECT OF DIFFERENT SOLVENTS ON PER CENT EXTRACTION YIELD FROM DRY WEIGHT OF LEAVES

\begin{tabular}{lcccc}
\hline \multirow{2}{*}{ Sample and local name } & \multicolumn{3}{c}{ Extraction yield (\%) in solvents } \\
\cline { 2 - 5 } & Acetone & Ethanol & Methanol & Chloroform \\
\hline A. marmelos (Beal) & 1.42 & 1.61 & 7.04 & 1.42 \\
S. cumini (Jamun) & 3.01 & 2.82 & 8.12 & 1.61 \\
P. pinnata (Karanj) & 2.63 & 3.81 & 6.81 & 1.45 \\
\hline
\end{tabular}

TABLE 2: EFFICACY OF BIO AGENTS ON MYCELIAL GROWTH OF F. OXYSPORUM F. SP. CICERI

\begin{tabular}{lcc}
\hline \multirow{2}{*}{ Treatment } & Radial mycelial growth $(\mathrm{mm})$ & Per cent inhibition \\
\cline { 2 - 3 } & $\boldsymbol{F . ~ o x y s p o r u m ~ c i c e r i ~}$ & F. oxysporum ciceri \\
\hline T. viride & 20.43 & $77.30(61.58)^{*}$ \\
P. fluorescens & 16.57 & $81.59(64.68)$ \\
Control & 90.00 & $0.00(0.00)$ \\
F test & Sig & Sig \\
SE $(M) \pm$ & 0.72 & 0.57 \\
CD at $(\mathrm{P}=0.01)$ & 2.83 & 2.21 \\
\hline
\end{tabular}

*Figures in parenthesis are arc sin transformed values, average of five replications

borne plant pathogenic fungi ${ }^{[21]}$ due to the fact that it was reported to contain phenazin $^{[22]}$, pyroluterin ${ }^{[23]}$ phloroglucinol $^{[24]}$ and siderophores ${ }^{[25]}$, which might be involved in the supersession of the wilt pathogen ${ }^{[26]}$. Muneeb et al. ${ }^{[27]}$ observed $84.79 \%$ mycelial inhibition of the F. oxysporum $f$. sp. ciceri by $T$. viride under in vitro condition.

Observations on interaction effect of solvents, leaves and concentrations on dry mycelial weight of F. oxysporum f. sp. ciceri were recorded and percent inhibitions were determined and presented in Table 3. Statistically analysed results clearly indicated the antifungal activity of the methanol extract of $A$. marmelos plant and its ability to control mycelial growth of F. oxysporum f. sp. ciceri. At $250 \mu \mathrm{l}(\mathrm{C} 1)$ concentration, S3P1 showed a maximum of $59.86 \%$ inhibition of test fungus followed by $58.89,58.80 \%$ reduction in $\mathrm{S} 3 \mathrm{P} 3$ and $\mathrm{S} 2 \mathrm{P} 1$, respectively and all these interactions were at par with each other. Lowest inhibition observed in the interaction of S4P2 with the test fungus at $250 \mu 1$ concentration (C1).

At $500 \mu \mathrm{l}(\mathrm{C} 2)$ concentration, $79.81 \%$ inhibition of the test fungus was observed in S3P1, followed by $76.42 \%, 75.43 \%$ inhibition by S3P3 and S2P1. An inhibition of $64.32 \%$ was recorded in S4P2. At $750 \mu 1$ (C3) concentration, $83.56 \%$ inhibition of test fungus was occurred in S3P1, 82.11\% inhibition occurred in S3P3 and $68.51 \%$ inhibition was recorded at the interaction with $\mathrm{S} 4 \mathrm{P} 2$. At the highest concentration of $1000 \mu 1,88.64 \%$ inhibition of mycelial growth of test fungus was recorded in S3P1, 85.30\% inhibition observed in interaction S3P3 inhibition of test fungus and $68.83 \%$ and $70.98 \%$ were recorded in interactions S4P2 and S4P3, respectively.

Ahanjan et al. ${ }^{[28]}$ reported 40.00 and $42.38 \%$ inhibition of mycelial growth of $F$. oxysporum by aqueous and methanol extract of $P$. persica, respectively at $500 \mathrm{ppm}$ concentration. Abdel-Monaim et al. ${ }^{[29]}$ tested extracts including Calotropis procera, which suppressed growth of $F$. oxysporum $f$. sp. lupini. Effects of methanol extract of A. marmelos and bio agents alone and in combination on chickpea wilt caused by $F$. oxysporum $f$. sp. ciceri under pot experiment was studied in the present investigation. Observations on per cent seed germination and wilt incidence at 30 and $60 \mathrm{~d}$ was noted and results are presented in Table 4.

Results in Table 4 revealed that, T9 (P. fluorescens $10 \mathrm{~g} / \mathrm{kg}$ seed $+T$. viride $4 \mathrm{~g} / \mathrm{kg}$ seed + methanol extract of $A$. marmelos) gave maximum seed germination $(94.33 \%)$, which was significantly greater than all the other treatments. Lowest percent germination (68.67\%) was reported in T10 (control). Minimum wilt incidence $(14.33 \%)$ at $30 \mathrm{~d}$ was exhibited in T9 (P. fluorescens $10 \mathrm{~g} / \mathrm{kg}$ seed $+T$. viride $4 \mathrm{~g} / \mathrm{kg}$ seed+methanol extract of $A$. marmelos), followed by $22.00 \%$ in $\mathrm{T} 6$ ( $P$. fluorescens $10 \mathrm{~g} / \mathrm{kg}$ seed $+T$. viride $4 \mathrm{~g} / \mathrm{kg}$ seed) and $\mathrm{T} 7$ (P. fluorescens $10 \mathrm{~g} / \mathrm{kg}$ seed $+T$. viride $4 \mathrm{~g} / \mathrm{kg}$ seed + methanol extract of $A$. marmelos). Maximum wilt incidence (59.67\%) at $30 \mathrm{~d}$ was observed in the control, followed by $41.33 \%$ in T3 (methanol extract of A. marmelos 2\%). Similar trends were recorded at $60 \mathrm{~d}$. Percent disease reduction was calculated and was found higher in T9 (69.31\%).

Abdel-Monain et $a l .{ }^{[29]}$ reported that the water 
TABLE 3: EFFECT OF INTERACTION MEANS OF SOLVENTS X PLANTS CONCENTRATIONS

\begin{tabular}{|c|c|c|c|c|}
\hline \multirow{2}{*}{$\begin{array}{l}\text { SxP×C } \\
\text { (solvent×plant×conc.) }\end{array}$} & \multicolumn{4}{|c|}{$\%$ inhibition over control } \\
\hline & C1 $(250 \mu \mathrm{l})$ & C2 $(500 \mu \mathrm{l})$ & C3 $(750 \mu \mathrm{l})$ & $\mathrm{C} 4(1000 \mu \mathrm{l})$ \\
\hline S1P1 & $58.63(49.97)^{*}$ & $73.22(58.84)$ & $76.60(61.07)$ & $78.78(62.58)$ \\
\hline S1P2 & $56.42(48.69)$ & $67.67(55.35)$ & $73.10(58.76)$ & $74.34(59.57)$ \\
\hline S1P3 & $57.69(49.42)$ & $70.97(57.40)$ & $74.44(59.63)$ & $78.76(62.56)$ \\
\hline S2P1 & $58.80(50.07)$ & $75.43(60.29)$ & $79.78(63.28)$ & $82.14(65.00)$ \\
\hline S2P2 & $57.52(49.32)$ & 71.91 (57.99) & $76.49(61.00)$ & $79.75(63.26)$ \\
\hline $\mathrm{S} 2 \mathrm{P} 3$ & $57.45(49.28)$ & $70.78(57.28)$ & $74.13(59.43)$ & $78.79(62.58)$ \\
\hline S3P1 & $59.86(50.69)$ & $79.81(63.31)$ & $83.56(66.09)$ & $88.64(70.30)$ \\
\hline S3P2 & $58.53(49.9)$ & $75.38(60.25)$ & $79.80(63.30)$ & $82.04(64.92)$ \\
\hline S3P3 & $58.89(50.12)$ & $76.42(60.95)$ & $82.11(64.98)$ & $85.30(67.45)$ \\
\hline S4P1 & $57.68(49.42)$ & $67.35(55.15)$ & $69.72(56.61)$ & $72.15(58.15)$ \\
\hline S4P2 & $55.40(48.10)$ & $64.32(53.32)$ & $68.51(55.87)$ & $68.83(56.06)$ \\
\hline S4P3 & $57.41(49.26)$ & $66.34(54.54)$ & $68.68(55.97)$ & $70.98(57.40)$ \\
\hline Control & 0.00 & 0.00 & 0.00 & 0.00 \\
\hline Source & & & $(M) \pm$ & C.D. at $(P=0.01)$ \\
\hline Solvent (S) & & & 04 & 0.17 \\
\hline Plants (P) & & & 03 & 0.13 \\
\hline Concentrations $(C)$ & & & 08 & 0.33 \\
\hline Solvent $x$ plants $(\mathrm{S} \times \mathrm{P})$ & & & 07 & 0.29 \\
\hline Solvent $\times$ concentrations & & & 08 & 0.33 \\
\hline Plants $\times$ concentrations & & & 07 & 0.29 \\
\hline Solvent $\times$ plants $\times$ concent & $5 \times P \times C)$ & & 14 & 0.54 \\
\hline
\end{tabular}

${ }^{*}$ Figures in parenthesis are arc sin transformed values, average of three replications. Solvents (S): S1-acetone, S2-ethanol, S3-methanol, S4-chloroform. Plant leaves (P): P1-A. marmelos leaf extract, P2-S. cumini leaf extract, P3-P. pinnata leaf extract. Concentrations (C): $\mathrm{C} 1-250 \mu \mathrm{l}, \mathrm{C} 2-500 \mu \mathrm{l}, \mathrm{C} 3-750 \mu \mathrm{l}, \mathrm{C} 4-1000 \mu \mathrm{l}$

TABLE 4: EFFECT OF P. FLUORESCENS, T. VIRIDE AND METHANOL EXTRACT OF A. MARMELOS ALONE AND IN COMBINATION ON CHICKPEA WILT CAUSED BY F. OXYSPORUM F. SP. CICERI

\begin{tabular}{|c|c|c|c|c|c|}
\hline \multirow{2}{*}{ S. No. } & \multirow{2}{*}{ Treatment } & \multirow{2}{*}{ Germination (\%) } & \multicolumn{2}{|c|}{ Wilt (\%) } & \multirow{2}{*}{$\begin{array}{c}\text { \% disease } \\
\text { control }\end{array}$} \\
\hline & & & $30 \mathrm{~d}$ & $60 \mathrm{~d}$ & \\
\hline T1 & $P$. fluorescens alone $(10 \mathrm{~g} / \mathrm{kg})$ & $83.33(65.91)^{*}$ & $24.00(33.42)^{*}$ & $40.00(43.66)^{*}$ & 56.70 \\
\hline $\mathrm{T} 2$ & T. viride alone $(4 \mathrm{~g} / \mathrm{kg})$ & $86.67(68.58)$ & $30.33(29.33)$ & $47.67(39.23)$ & 48.38 \\
\hline T3 & Methanol extract of $A$. marmelos alone $2 \%$ & $73.67(59.13)$ & $41.33(40.01)$ & $58.00(49.60)$ & 37.18 \\
\hline T4 & Methanol extract of $A$. marmelos alone $3 \%$ & $76.33(60.89)$ & $39.33(38.84)$ & $56.33(48.64)$ & 38.99 \\
\hline T5 & Methanol extract of $A$. marmelos alone $4 \%$ & $81.00(64.16)$ & $35.67(36.67)$ & $53.00(46.72)$ & 42.60 \\
\hline T6 & P. fluorescens $(10 \mathrm{~g} / \mathrm{kg})+T$. viride $(4 \mathrm{~g} / \mathrm{kg})$ & $90.67(72.21)$ & $22.00(27.97)$ & $32.00(34.45)$ & 65.33 \\
\hline $\mathrm{T} 7$ & $\begin{array}{l}\text { P. fluorescens }(10 \mathrm{~g} / \mathrm{kg})+\text { methanol extract } \\
\text { of } A \text {. marmelos } 4 \%\end{array}$ & $89.67(71.25)$ & $22.00(31.09)$ & $32.33(38.25)$ & 64.98 \\
\hline T8 & $\begin{array}{l}\text { T. viride }(4 \mathrm{~g} / \mathrm{kg})+\text { methanol extract of } A . \\
\text { marmelos } 4 \%\end{array}$ & $92.33(73.93)$ & $26.67(27.97)$ & $38.33(34.65)$ & 58.48 \\
\hline T9 & $\begin{array}{l}\text { P. fluorescens }(10 \mathrm{~g} / \mathrm{kg})+T \text {. viride }(4 \mathrm{~g} / \mathrm{kg}) \\
\text { +methanol extract of } A \text {. marmelos } 4 \%\end{array}$ & $94.33(76.23)$ & $14.33(22.25)$ & $28.33(32.16)$ & 69.31 \\
\hline T10 & Control (pathogen inoculated) & $68.67(55.96)$ & $59.67(50.57)$ & $92.33(73.93)$ & 0.00 \\
\hline SE $(M) \pm$ & & 1.41 & 0.72 & 1.06 & - \\
\hline$C D P=0.01)$ & & 5.22 & 2.65 & 3.90 & - \\
\hline
\end{tabular}

extracts of E. jambonala leaves, C. colocynthis fruits and $N$. oleander leaves resulted in highest reduction in disease severity caused by $F$. oxysporum f. sp. lupini. Results obtained showed that all the tested plant extracts suppressed growth of $F$. oxysporum $f$. $s p$. Cicero to different degrees. Also, methanol extracts inhibited growth of the pathogen more than the other solvent extracts. A. marmelos plant extract showed the highest effect in reducing radial growth of the pathogen compared to other extracts. Several higher plants have been found to possess inhibitory effects against mycelial growth of different phytopathogenic fungi ${ }^{[30]}$.

The present study revealed that methanol extract of $A$. marmelos in poisoned food technique inhibited highest growth of test pathogen at the concentration of 1000 $\mu 1$. Methanol was the best solvent for extraction of 
antifungal constituents from the medicinal plant leaves. Methanol extract of $A$. marmelos exhibited superior activity against $F$. oxysporum $f$. sp. ciceri. $T$. viride and $P$. fluorescens were found to be effective against F. oxysporum $f$. sp. ciceri. T. viride and P. fluorescens were compatible with each other as well as with methanol extract of $A$. marmelos. In pot culture study, combined application of $T$. viride, P. fluorescens and the methanol extract of $A$. marmelos as seed treatment was found effective. Thus, chickpea wilt could be managed by the integration of various practices like, seed treatment with bio agents and plant extract. Further field experiments are required to investigate the in vivo effects of these medicinal plants extracts in comparison with some chemical fungicides for the management of wilt of chickpea.

\section{Conflict of interest:}

All authors declare no conflict of interests.

\section{Financial support:}

Nil.

\section{REFERENCES}

1. Mishra SK, Raja R. Systemic acquired resistance: review. Ann Agric Res 1999;20:249-59.

2. Hada D, Sarma K. A Review: Plant extracts a new source of antimicrobial potential. Res J Pharm Biol Chem Sci 2014;5:597-628.

3. Nagpurne VS, Patwari JM. Studies on antimicrobial activity of medicinal plants against seed-borne pathogenic fungi. Int Res J Biological Sci 2016;5:54-6.

4. Varma J, Dubey NK. Prospectives of botanical and microbial products as pesticides of tomorrow. Curr Sci 1999;76:172-9.

5. Singh SK, Sarma BK, Srivastava JS, Singh UP, Ray AB. Antifungal activity of $\& 3$-Alstovenine, a plant alkaloid isolated from Alstonia venenata. Folia Microbiol 1999;44:510-12.

6. Phulan R, Vasisht K, Khullar N. Bio-autography an efficient method to check the in vitro antimicrobial activity of Aegle marmelos against enteric pathogens. Instit Integr Omics App Biotech J 2013;4:4-9.

7. Gupta O, Katasthane SR, Khare MN. Fusarium wilt of chickpea (Cicer arietinum L.). Agric Rev 1986;7:87-97.

8. Singh J, Ratan V, Singh N. Management of wilt of chickpea. Annals Plant Prot Sci 2009;17:248-9.

9. Haware MP, Nene YL. Symptomless carriers of the chickpea wilt Fusarium. Plant Dis 1982;66:250-1.

10. Haware MP, Nene YL, Rajeshwari R. Eradiation of Fusarium solani f. sp. ciceri transmitted in chickpea seed. Phytopath 1978;68:1364-7.

11. Thenmozhi M, Bhavya PK, Rajeshwari S. Compounds identification using HPLC and FTIR in Eclipta alba and Emilia sonchifolia. Int J Engin Sci Technol 2011;3:292-8.

12. Khan ZS, Shinde VN, Bhosale NP, Sahera N. Chemical composition and antimicrobial activity of angiospermic plants. Middle-East J Scientific Res 2010;6:56-61.
13. Al-Rahmah AN, Mostafa AA, Abdel-Megeed A, Yakout SM, Hussein SA. Fungicidal activities of certain methanolic plant extracts against tomato phytopathogenic fungi. African J Microbiol Res 2013;7:517-24.

14. Vincent JH. Distortion of fungal hyphae in the presence of certain inhibitors. Nature 1947;15:850.

15. Latha P, Anand T, Ragupathi N, Prakasam V, Samiyappan R. Antimicrobial activity of plant extracts and induction of systemic resistance in tomato plant by mixture of PGPR strains and zimmu leaf extract against Alternaria solani. Biol Control 2009;50:85-93.

16. Panse VG, Sukhatme PV. Statistical methods for agricultural Workers. New Delhi: ICAR Publication; 1978.

17. Lily Trivedi, Rathi YPS. Integrated management of seed borne Fusarium oxysporum f. sp. ciceri in chickpea wilt complex. World J Pharm Pharm Sci 2016;5:2392-402.

18. Mohamed EH, Nayla EH, AbdAlla MAE. Control of chickpea wilt caused by Fusarium oxysporum f. sp. ciceris with botanical extracts and fungicides. Int J Curr Microbiol Appli Sci 2016;5:360-70.

19. Kala C, Gangopadhyay S, Godara SL. Eco-friendly management of wilt caused by Fusarium oxysporum f.sp. ciceri in chickpea. Legume Res 2016;39:129-34.

20. Kumbhar AS, Gade RM, Shitole AV, Bandgar MS. Utilization of spent mushroom substrate with bio control agents for management of wilt of chickpea. J P1 Dis Sci 2016;11:113-15.

21. Burr A, Ortuno A, Armero T. Phosphate solubilizing effect of Aspergillus niger and Pseudomonas. Microbiologia Espanola 1998;30:113.

22. Gurusiddaiah S, Weller DM, Sarkar A, Cook RJ. Characterization of an antibiotic produced by a strain of $P$. fluorescens inhibitory to Gaemannomyces graminis var. tritici and Pythium spp. Antimicrob Agents Chemother 1986;29:488-95.

23. Burkhead K, Geoghegan MJ. Antibiotics. In: Burkhead K, editor. Soil-borne Plant Pathogens. New York: Macmillon; 1994. p. 368.

24. Howell CR, Stipanovic RD. Suppression of Pythium utlimuminduced damping-off of cotton seedlings by Pseudomonas fluorescens and its antibiotic pyoluteorin. Phytopath 1980;70:712-15.

25. Sakthivel N, Sivamani E, Unnmalai N, Gananamanickam SS. Plant growth promoting rhizobacterial in enhancing plant growth and suppressing plant pathogens. Current Sci 1986;55:22-5.

26. Fridlender M, Inbar J, Chet I. Biological control of soil borne pathogens by a $\beta-13$ glucanase producing Pseudomonas cepacia. Soil Biol Biochem 1993;25:1211-21.

27. Muneeb A, Vaid A, Razdan VK. Evaluation of different measures to control wilt causing pathogens in chickpea. J Plant Prot Res 2010;51:55-9.

28. Ahanjan M, Raghavendra MP, Raveesha KA. A novel antifungal phenolic compound from Parrotia persica. African J Biochem Res 2009;3:174-80.

29. Abdel-Monaim, MF, Abo-Elyousr KAM, Morsy KM. Effectiveness of plant extracts on suppression of damping-off and wilt diseases of lupine (Lupinus termis Forsik). Crop Prot 2011;30:185-91.

30. Mohamed NH, El-Hadidy AM. Studies on biologically active constituents of Verbascum eremobium Murb. and its inducing resistance against some diseases of cucumber. Egypt J Phytopathol 2008;36:133-50. 